\title{
Principal Leadership Based on Justice and Tolerance Ethics in Vocational High Schools
}

\author{
Amiruddin Siahaan', Rizki Akmalia², Budi Suhartono3, Rini Dewi Andriani4, \\ Mulkan Hasibuan5
}

DOI: $10.35445 /$ alishlah.v13i3.880

\section{Article Info}

Keywords:

Leadership,

Ethics of Justice,

Tolerance

Kata kunci:

Kepemimpinan,

Keadilan,

Toleransi,

\section{Abstract}

This study aimed to determine the pattern of principals' leadership in implementing fair and tolerant leadership towards teachers and students who have different ethnicities, races, and religions. This study uses qualitative research methods, with the type of descriptive research. The subjects of this study were 6 teachers and 4 Vocational High School students. This study uses primary data and secondary data as data sources. At the same time, the data collection tools are through interviews, observation, and documentation. Data analysis techniques used are data reduction, data presentation, and concluding. The test of data validity is done by extending the period of observation, triangulation, and careful observation, and conducting member and checks so that the information obtained can be used in research in accordance with what was meant by the informant. Based on the findings, it is obtained that the principal's ethics of justice can be seen through the implementation of policies in his daily life, such as determining rewards and punishments based on fairness and tolerance regardless of race, ethnicity, and religion.

\begin{abstract}
Abstrak
Tujuan penelitian ini adalah untuk mengetahui pola kepemimpinan kepala sekolah dalam menerapkan kepemimpinan yang adil dan toleran terhadap guru dan siswa yang berbeda suku, ras dan agama. Penelitian ini menggunakan metode penelitian kualitatif, dengan jenis penelitian deskriptif. Subjek penelitian ini adalah 6 orang guru dan 4 siswa SMK. Penelitian ini menggunakan data primer dan data sekunder sebagai sumber data. Sedangkan alat pengumpulan datanya melalui wawancara, observasi dan dokumentasi. Teknik analisis data yang digunakan adalah reduksi data, penyajian data, dan penarikan kesimpulan. Untuk menguji keabsahan data dilakukan dengan cara memperpanjang jangka waktu pengamatan, triangulasi, dan pengamatan cermat, serta melakukan member and check agar informasi yang diperoleh dapat digunakan dalam penelitian sesuai dengan yang dimaksud oleh informan. Berdasarkan temuan, diperoleh bahwa etika prinsip keadilan dapat dilihat melalui implementasi kebijakan dalam kehidupan sehari-harinya seperti dalam
\end{abstract}

\footnotetext{
${ }^{1}$ Universitas Islam Negeri Sumatera Utara, Medan, Indonesia

Email: amiruddinsiahaan@uinsu.ac.id

${ }^{2}$ STAI JM Tanjung Pura, Langkat, Indonesia

Email: rizki.akmalia@gmail.com

3 Universitas Islam Negeri Sumatera Utara, Medan, Indonesia

Email: budisuhartono@uinsu.ac.id

4 STAI AL-Hikmah, Medan, Indonesia

Email: rinidwiandriani@uinsu.ac.id

5 Universitas Islam Negeri Sumatera Utara, Medan, Indonesia

Email: mulkan.hasibuan@uinsu.ac.id
} 
menentukan penghargaan dan hukuman atas dasar keadilan dan toleransi tanpa membedakan ras, suku, dan agama.

\section{INTRODUCTION}

As the head of a school, the principal is the most powerful person in the organization. Because of the trust placed in him or her, the principal wields considerable power when it comes to formulating and enforcing school policies. Especially those in the field of justice and tolerance education. When it comes to fostering, guiding and leading all school resources in accordance with their duties and responsibilities, the head of school is in a unique position. The key to achieving the hoped-for results (Chairunnisa et al., 2020). Some argue that the school's principal, as the school's top manager, is obligated to perform administrative duties and coordinate the school's resources (Rizkita \& Supriyanto, 2020). One can infer from this statement that a principal has complete authority over how his institution is run. Teachers clearly dislike the effect of the school's discipline policy, which requires them to be on time for class.

The most effective school leaders are constantly looking for new ways to raise the bar for student learning. One aspect of putting the process standard into action is to enhance quality. For a school to be successful, the principal must be able to handle any issues that may arise in the classroom. Principals in this situation must be able to lead educational institutions and identify and solve problems that arise during learning, according to Hamid (2018). The responsibilities of a school administrator come with a hefty price tag. As a principal, you must be able to act on your role as educational leadership to promote tolerance among teachers and adhere to the ethics of justice.

Ethical principles can be derived from justice, which is a component of ethics that can be applied to various aspects of society (Zulkarnain, 2018). In the institutions he leads, a good leader still adheres to the principles of justice. In order to be a leader with high ethical standards, one must have the support of those in positions of power, rather than relying solely on one's own abilities. According to Allyn and Bacon, the implementation of a plurality of perspectives in educational leadership is a political issue due to the fact that all school domains are regulated. Boards of education can be established at the local level, either by elected officials or by people appointed by them (Ghanem, 2018). It is possible to conclude from some of the above statements that a leader should establish a good relationship with the relevant authorities in order to create quality educational activities and achieve the institution's specific goals.

Equal rights are viewed as a single entity or container by humans (Suheri, 2018). According to Allyn and Bacon, justice is the most important issue in today's society because people's actions can have an immediate impact on others, unlike in previous societies. People's actions can have an impact on others in today's close-knit society, where justice is the most pressing issue. Immanuel Kant believes that the greatest injustice is the greatest justice. To put it another way, the purpose of perfect justice is to make injustice possible (Johan Nasution, 2014). The above statement by Immanuel can be taken to mean that every act of justice must be accompanied by an act of injustice. As a result, a person in a position of authority in education must be able to recognize when it is appropriate to be fair and when it is not.

Tolerance is always in harmony with justice or injustice. When it comes to justice, tolerance has a lot in common with it. An open, airy disposition, willingness and tenderness are all examples of tolerance. International Organization for Standardization (Unesco) defines tolerance as "respect, acceptance and mutual respect" (Casram, 2016). Tolerance is also defined as a fair and unbiased approach to people who have differing viewpoints, conduct, ethnicity, religion, nationality, and so on (Supriyanto, 2017).

Some research findings regarding the application of tolerance values among religious people can be seen in the daily attitudes of students (Gita, 2018). Jati (2014) investigates the tolerance of $\mathrm{m}$ in students' multicultural education. Fuad (2015) researches the educational development of 
religious tolerance in children. Anwar (2021) examined religious tolerance through the lens of Islamic religious education. There has been no research to date that examines principals' leadership patterns in extending fair and tolerable leadership to teachers and students from diverse tribes, races, and religions. It has developed into a novel aspect of this research. The purpose of this study is to determine how tolerance attitudes between fellow students, fellow teachers, and between principals and teachers and students differ and how the principal applies Ethical Justice when making decisions and enforcing a policy.

\section{METHODS}

This research employed qualitative methods, a subset of descriptive research that aims to create a clear, systematic, and accurate picture of facts, properties, and relationships. The issues being investigated relate to a variety of existing conditions and situations that occur in today's educational institutions. This research was conducted at SMK Kita Matapao, which is located in Sei Bamban, specifically on a plantation in the Serdang Bedagai Regency's Sei Bamban subdistrict. Ten individuals participated in this study ( 6 teachers and 4 students). Students who are educated in Islam and Christianity are included in the class, allowing for a more interesting and appropriate field study. The study examined the processes, attitudes, and behaviors of students and teachers in relation to religious tolerance. Each religion has nurtured its adherents directly under the tutelage of its religious teachers. They tolerated one another as believers by respecting their respective holy days.

The study used primary data and secondary data as data sources in obtaining data and information. While data collection tools through interviews/interviews, observations, documentation, and literature studies. The interview was conducted to explore various information about tolerance among religious people and how the ethics of justice are applied by the principal in decision making. In this study, researchers interviewed 3 teachers who are diverse in Islam and 3 teachers who were Christian by random sampling, for observation was carried out with the aim of obtaining data on school activities related to tolerance. Researchers observed activities held at school institutions, which were related to the ethics of justice and tolerance. In this case, the researchers used the medium of a smartphone to record any activity that occurred. From existing records, organizing was done where certain grouping parts are directly related to leadership ethics and tolerance.

Documentation was done to obtain data in photos and other sources. In contrast, the study of literature was carried out to obtain materials or sources as information from a theoretical foundation by studying and studying books related to teachers in the world. educational institutions, especially in SMK Kita Matapao. Researchers first searched for information about the ethics of justice and tolerance. From various sources obtained, then organize more specific information, as a reference material in relation to the focus of research. This study did not use population, but in accordance with situational or social situations consisting of three elements, namely places, actors, and activities of each other interacting.

The data that has been obtained from the interview is compiled incomplete records after being supported from observations and documentation. Then the data analysis technique used in this study refers to a Milles \& Huberman concept (Sugiyono,2013: 337): data reduction, data presentation, and conclusion withdrawal. The reduced data is data that provides a sharp picture of the results of researchers' observations related to tolerance among religious people in SMK Kita Matapao. Then the researchers presented data that has been systematically compiled with the form of narrative text. Later, it provides convenience in the withdrawal of temporary conclusions so that it needs to be verified to reach an objective conclusion. For testing the validity of the data was carried out by extending the period of observation, triangulation, and careful observation, and holding a member and check so that the information obtained can be used in research in accordance with what the informant means (Sugiyono,2012: 270). Data findings can be declared valid if there is no difference between what the researcher reported and what happened to the object studied. 
As for the design in this study, it can be seen in the following flowchart:

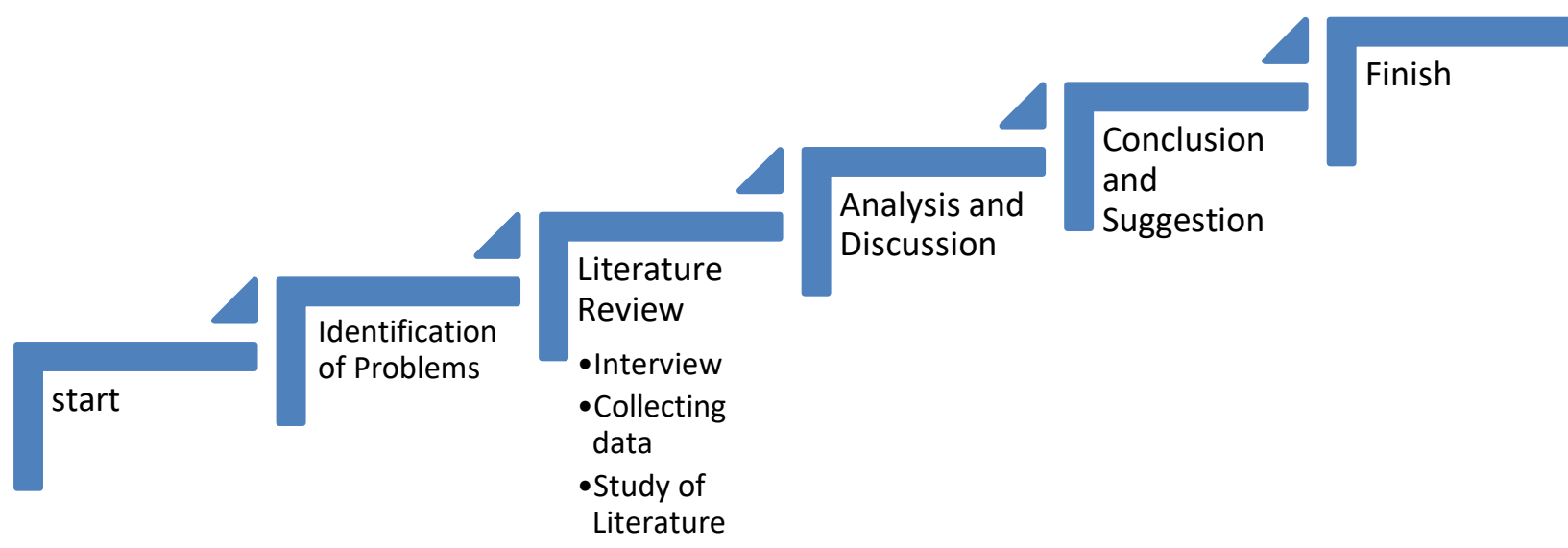

\section{FINDINGS AND DISCUSSION}

Based on observations made, researchers found several posters displayed on the school grounds in the form of appeals to maintain a friendship despite differences. In line with that, the results of the interview with the principal provided an explanation that there needs to be a reminder for every school resident, especially students, to take care of each other: friendship or kinship. Therefore, there was an initiative to create some appeal posters related to it. Furthermore, the results of the interview with the principal explained that if encountered learners violate the rules, then the teacher BK will give warnings and reprimands to the student in question. If there is a problem that is larger in nature, the principal, in this case, is involved or participates. Related to the problems of both learners and educators, even though the principal was a Muslim, still has Justice regardless of differences and religion in determining whether learners.

A harmonious life about religious people has been built in SMK Kita Matapao for a long time. This was reinforced by the results of an interview with the principal who explained that although all learners are side by side between religions, they still have mutual respect for each other. Others, thanks to the guidance of their respective religious teachers. With the background of two different religions, it could be interpreted that each religion respects each other's respect between believers. Through interviews conducted with teachers revealed that the principal was always active in coordinating and supervising all learners and educators when implementing religious activities. Likewise, the treatment and ethics of the principal of the school's worship facilities for Muslims even though it is adjacent to the mosque, but the principal managed and coordinated students' religious activities. Not only Muslims, the principal also respects a room that was used as a place to study and worship for Christians.

\section{Ethical educational leadership of Justice}

The results of an interview conducted with one of the Islamic religious teachers revealed that:

"The principal as the leader of this educational institute has generally carried out the ethics of Justice. This ethics of Justice could be seen when the principal applies a policy in the daily activities in this school. Concrete examples such as, when there were Muslim teachers using relatively tight teaching clothes and hijabs that did not stick 
out to the chest, the principal called and Rebuke him subtly. Likewise, with teachers who were Christian when using skirts that were too high and above the knee, then the principal also called and reprimanded him subtly."

In addition, the Christian teacher also explained in the interview that:

"The principal in making rewards and punishment did not look at religious race, even though the principal is Muslim, but the treatment of educators who were Christian remains the same with the Muslim religion. Likewise, with pieces of training and workshops, the principal thoroughly sent teachers both Muslim and Christian. Not only that, the treatment of learners was also the same without anything distinguished".

Similar to the results of the interview above, that two students who were Christian when interviewed also explained that:

"The Headmaster always paid attention when we wandered outside the lesson hours and asked what subjects are currently. After we answered the subjects of Christianity, he immediately asked us to enter the class and study religion diligently according to our beliefs. The Headmaster also rebuked us well without any anger or other facials. After that, the Headmaster passed so that our teaching and learning process was not disturbed".

Based on the interviews with several teachers and learners above, it could be concluded that the headmaster's leadership's tolerance and ethics of Justice at SMK Kita Matapao is already good. The principal always applied an attitude of tolerance, respect and had a high concern. Not only that, in making decisions and implementing policies, of course, the principal applied Justice so that no one was disappointed with each other because of different views between tribes, races, and religions.

In addition, ethics run by the principal was a guideline that each individual or group has regarding what was right and wrong based on moral standards that apply in society. Ethics does not question the human condition but rather questions how humans should act based on values and norms (Miswardi et al., 2021). And actually, tolerance between religious people has been running for a long time from the previous Principal, meaning that no one is hurt and harmed, let alone in intervention, because everyone respects each other. The tolerance that is implemented essentially is airy and willing in accordance with tolerance that is peaceful, open, and receptive to the beauty of differences, respecting individuals and differences, knowing to appreciate the good in others and situations (Supriyanto, 2017).

In this regard, it was found that some relevant investigations conducted based on cases of religious freedom violations in 2011 increased by $18 \%$ or amounted to 92 cases. The results of this study concluded that local wisdom is able to instill the values of tolerance among religious people seen from the daily attitudes of students.

Based on the results of previous research that has been described above, it can be concluded that maintaining tolerance in the scope of education, especially in educational institutions, is a thing that are considered important. Several things distinguish between this research and research that has been done before, wherein this study, the dimension that is a reference is leadership. It refers to how Justice in every procedure is carried out as well as policies implemented to increase tolerance among religious people.

\section{CONCLUSION}

Based on the results of the research, it can be concluded that the school in this case referred to as leadership education based on the ethics of Justice has understood how fair attitude in the management of its duties and responsibilities. His leadership has also implemented participatory leadership, which is a fair leader in implementing a policy in accordance with the needs and integrity 
of this school. Tolerance among religious people has also been implemented by the principal well with various policies that have been established. From tolerance in accordance with the principle of tolerance where you have had peace, open and receptive to the beauty of differences, appreciate individuals and differences, know to appreciate the good in others and situations. Further research can be conducted on the obstacles faced in the application of Justice and religious tolerance. The results of this study can be used as a reference for learning resources in the classroom.

\section{REFERENCES}

Anwar, C., Ali, S., \& Putra, A. H. (2021). Tolerance Between Religious People through the Application of Islamic Religious Education Learning (Case Study: SMAS PARAMARTA 1 As White as Many). Encyclopedia: Journal of Education and Learning Innovation, 1(01), 29-35.

Casram, C. (2016). Building Religious Tolerance in a Plural Society. Insights: Scientific Journal of Religion and Socio-Culture, 1(2), 187-198. https://doi.org/10.15575/jw.v1i2.588

Chairunnisa, E., Najiyah, C., Salsabila, H., \& Cendekia Dikara, W. Na. (2020). Quality Leadership: The Concept of The Development of Islamic Educational Institutions. Progresiva: Journal of Islamic Thought and education, 9(1), 26. https://doi.org/10.22219/progresiva.v9i1.12517

Ghanem, B.M. (2018). Ethical leadership in education and its relation to education management ethics. European Journal of Education Studies, 4(6), 243-256. https://doi.org/10.5281/zenodo.1245865

Fuad, N. (2015). The cultivation of religious tolerance in children through education. Societas Dei: Journal of Religion and Society, 2(1), 252-252.

Hamid, H. (2018). School-Based Management. Al-Khwarizmi: Journal of Mathematics and Natural Sciences Education, 1(1), 87-96. https://doi.org/10.24256/jpmipa.v1i1.86

Johan Nasution, B. (2014). Philosophical Studies of the Concept of Justice From Classical Thought to Modern Thought. Yustisia Journal of Law, 3(2). https://doi.org/10.20961/yustisia.v3i2.11106

Jati, W. R. (2014). Religious Tolerance in Multiculturalism Education, Catholic High School Of East Yogyakarta. Journal of Horizons Education, 33(1).

Miswardi, Nasfi, \& Antoni. (2021). Ethics, Morality and Law Enforcement. Tower ofScience, 15(2), $150-162$.

Rizkita, K., \& Supriyanto, A. (2020). Comparison of educational leadership in Indonesia and Malaysia in an effort to improve the quality of education. Journal of Accountability of EducationManagement, 8(2), 155-164. https://doi.org/10.21831/jamp.v8i2.32362

Suheri, A. (2018). The Form of Justice in Society Is Reviewed From a National Legal Perspective. MORALITY: Journal of Legal Sciences, 4(1), 60-68.

Supriyanto, A. \& W. A. (2017). Operational Aspects of Peace, Respect. Scientific Journal of Counsellia, 1,61-70.

Zulkarnain, I. (2018). Theory of Justice: "The Influence of Aristotle's Ethical Thought on Ibn Miskawaih's Ethical System." Journal of Madani: Science, Technology and Humanities, 1(1), 143-166. https://doi.org/10.33753/madani.v1i1.8 